Robert Burgoyne, University of St Andrews

\title{
The Dark Power of Belonging: The T-Shirt
}

Abstract: In The T-shirt, disagreement overflows into brutal confrontation, as the two characters provoke each other to act out roles preordained by the power of symbols. What Freud called the "narcissism of minor differences" is rendered here as social pathology, dramatized in miniature in the violent encounter of two ordinary people

Keywords: Violence, nationalism, religion, flag, symbols, America, Slovakia, baseball.

The T-Shirt provides a short, brutal lesson in the micro-politics of contemporary life, where symbols of belonging -- the flag, the t-shirt, the head scarf -- have acquired an almost occult power. Freud described the intensity of emotion generated by seemingly mundane signs of distinction and affiliation as the "narcissism of minor differences" (Freud 305: 1930). In the US, and in many other nations, what once could be accurately described in this way has now been amplified to a surprising level of social pathology. The recent controversy over the Confederate battle flag in Charleston, South Carolina is a case in point. Understood as a symbol that crystallizes the continuing clash between two historical narratives around race, the Confederate battle flag has also been associated with the racial murder of nine black people in a church in Charleston. In the media sphere that was created around the murders, the flag itself assumed a kind of demonic agency, seen both as a symbol of race hatred and as a standard of racial purity, as an emblem of death and as a banner of ethnic survival.

The pathological undercurrents that flow through the symbols of belonging are illuminated in the short film The T-Shirt with special force. Two young men find a strong connection in their mutual love of baseball, their appreciation for America, and for the flag that hangs in the shop. The word "God " on the t-shirt of one of the men seems to confirm and solidify their bond. But then the message on the t-shirt is 
revealed in full, or seemingly so. An argument that at first appears to be a simple disagreement spirals out of control, as the offended party draws a gun and threatens the young man wearing the t-shirt, who in turn bashes the gun-wielding man with a baseball bat.

Here, the banal, mundane trappings of contemporary life, a t-shirt, an American flag on the wall, baseball, the crucifix, become something like battlefield positions, to be defended and held at all costs. The film reminds us of the many violent incidents fueled by perceived disrespect to cultural symbols -- the rampages sparked by ostensible disparagement of Mohammed or the Koran, the controversies and emotions surrounding the wearing of the head scarf, or the showing of women's hair, the offense of wearing the wrong colors in neighborhoods ruled by gangs -- the contemporary investment in symbols of belonging speaks to an atavistic impulse in modern life. Nor do these symbolic investments and the extreme reactions to them always refer to some long-standing tradition. In the recent Umbrella Movement protests in Hong Kong, for example, and in the anti-junta protests in Thailand, the three finger salute from The Hunger Games (2012) was adopted as a symbol for the protests, a silent gesture of solidarity taken from popular film and fiction that provoked the Thai police to arrest those giving the salute. As the New York Times reported: "A Thai theater chain has withdrawn the latest Hunger Games movie (2012) after several student protesters were detained for using a gesture taken from the films, a three-finger salute of resistance to authoritarian government. The salute, which in the movies is a daring act of silent rebellion, began to appear here in the weeks after the May 22 coup. The authorities warned that anyone raising it in public could be subject to arrest" (Mydans 2014).

In The T-Shirt, symbols of collective identity dominate the exchange between the two characters, and channel the conversation into a hostile, nearly fatal contest. While the psychology of frustration, loss, and emotional rigidity is clearly expressed in the behavior and speech of both characters, what interests me here is the augmentation, the amplification of emotion created by symbols of belonging, as if 
the iconography of state and religion carried both a magical and a malign power. The conversational exchange that opens the dialogue begins with a sense of fraternity -- a shared love of baseball, an appreciation for America, expressed in the languages of Slovakian and English. As the conversation descends to a series of challenges, however, triggered by the line on the front of Tomas' t-shirt, "'God is dead." (Nietzsche), each character begins to define the other in increasingly aggressive ways, until blood is finally drawn.

The formal features of the film exhibit a striking economy of expression. The hand held camera creates a sense of unsteadiness, enough to keep the viewer from settling into relaxation. Similarly, the black and white cinematography holds the viewer's attention on the faces of the two characters. The subdued cutting and minimal use of close-up is also effective. Mark has thrown some money on the counter and told Tomas to buy another t-shirt, that Tomas' t-shirt is "stupid." Tomas, without touching the money, snaps it back toward Mark, who is now departing the shop. Tomas then utters a direct insult under the breath. Here, a dramatic pause occurs, as the camera zeros in on Mark's reaction, a piece of visual punctuation that reads like an exclamation point, creating a pause and a break point in the action. Soon the characters are engaged in a duel in which a dead brother, a dog, God and the Taliban are brought out and played like so many cards in a game of high-stakes poker.

The frequent invocations of America in the film, from the opening and closing Gospel music, to the God Bless America slogan pasted over Mark's brother's picture, to his Texas license plate, to baseball and the American flag, seem to call for a political reading, which the director, Hossein Martin Fazeli has said is present but of minor importance: "there is a political layer in T-Shirt, but I think it's a secondary layer. It is there and it shows itself first, but it's not really what the film's about. I think the film is, first and foremost, about the absurdity of human conflict" (Fazeli, in Raskin, 2008). The American iconography that pervades the film, however, calls for a fuller account. Created in 2006, the film was made at the height of the George W. 
Bush presidency, and at the low point of the war in Iraq and Afghanistan. The odd detail of the Texas license plate, which would imply that Mark had shipped his car over to Slovakia for what seems to be a short visit, appears to be an intentional departure from plausibility in order to link Mark specifically to Texas culture. The uniformed portrait of his brother taped to the car glove box also seems somewhat unrealistic. And as we cut to the interior of the shop, we hear on the baseball broadcast the disconcerting words of an announcer talking about a young man being escorted from the park, shielded from an unruly crowd the night before. Although the lyrics of the Gospel song that introduces the film insist on the word "peace," a lyric that recurs multiple times, it is violence and its historical residue that dominate the opening, casting a shadow over the film. Indeed, one of Tomas' first remarks is about Slovakia being The Wasteland, a reference, among other things, to the book entitled Pustatina that sits on Tomas' counter -- a Slovakian translation of TS Eliot's famous lament written in the aftermath of WWI. As one writer says about The Tshirt, "What if that stranger were America itself, wounded and aggressive, incapable of going beyond its own dominant paradigms?" (Alegi 2008).

In my view, the political reading of Mark as an allegory of America in the 21st century, complete with his pistol pointing command to an unlucky customer who has stumbled into the shop -- "I said Shop!" -- falls just short. The psychological nuance and dramatic truth of the encounter is lost in such a reading. Rather, the film strikes me as deeply poignant: the characters seem locked into roles that appear distant from their basic natures. In effect, the symbols of nation and religion speak through the characters, ventriloquizing the two young men, prompting utterances, both pro and con, patriotic and anti-nationalist, religious and anti-fundamentalist, that are at one and the same time eloquent and unbending. Each of the characters seems to be playing out a role that has been prescribed for him, and each is diminished as a result.

The American wielding a pistol, insisting on the rectitude of his twin ideals of God and Nation, and the Slovak wielding a baseball bat asserting the right to his 
own territory and his own beliefs, propel the conflict to its violent conclusion, whose pathos and absurdity is made manifest only in the last shot of the film, as the words on the back side of Tomas' t-shirt now become visible: "Nietzsche is Dead" (God).

\section{References}

Alegi, Daniel (2008), "Notes on T-shirt: fact and fiction with no time to think." P.O.V. - A Danish Journal of Film Studies, No. 25, March 2008.

http://pov.imv.au.dk/Issue_25/section_2/artc4A.html Accessed July 16, 2015.

Freud, Sigmund (1930), Civilization and its Discontents, Standard Edition, Hogarth Press, London 1953: 21: 191-208

Mydans, Seth (2014), “Thai Protesters Are Detained After Using 'Hunger Games' Salute." New York Times, 20 November 2014.

http://www.nytimes.com/2014/11/21/world/asia/thailand-protesters-e -gamessalute.html Accessed July 16, 2015.

Raskin, Richard (2008), "An interview with Hossein Martin Fazeli on T-Shirt" P.O.V. - A Danish Journal of Film Studies, No. 25, March 2008.

http://pov.imv.au.dk/Issue_25/section_2/artc2A.html Accessed July 16, 2015.

Ross, Gary (2012), The Hunger Games. US: Color Force Films.

\section{Contributor details}

Robert Burgoyne is Professor and Head of the Department of Film Studies at the University of St Andrews. His work centers on historiography and film, with emphasis on American cinema and national identity. Recent publications include Film Nation: Hollywood Looks at U. S. History (revised edition, University of Minnesota, 2010) and The Epic Film in World Culture (Routledge/AFI, 2011).

E-mail: Robert.Burgoyne0@gmail.com 
